\title{
An Example of Art Management in Java: Art Management and Community Management Using Local Folk Art
}

\section{Kaori Okado}

Research Fellow, Urban-Culture Research Center, Osaka City University,558-8585 Japan email: kaoriokado@gmail.com

\begin{abstract}
In the present study, I examine the activities of a community network called Tlatah bocah at Mount Merapi and discuss their methods of art management and the benefit of them to the communities involved. They have been conducting festivals of folk performing arts for children and scholarship programs while very much respecting participants' autonomy. Many benefits were gained by the communities involved. This kind of structure can be called "community management". I demonstrate that this new system can add a new role and new value to traditional performing arts, empowering local communities.
\end{abstract}

Keywords: Art management, Community management, Traditional folk, performing art

\section{INTRODUCTION}

In recent years, the role of art in society has been changing rapidly everywhere in the world. Not only has art come to be valued for its own sake--distinct from any social function--but also art is used as a tool in a socially transformative way. In some ways, we can say that art has had social functions since ancient times and has been used as a tool in some societies. Some of the arts were used as a symbol of power of kings and the aristocracy, and also for many kinds of rituals. Also, arts were once thought useful by the ruling class to instruct the lower classes. However, in recent years, we can see many artistic activities empower people or communities in difficult situations. In this way, the role of art is widened in present society. For example, in Japan, many activities using art have been conducted that empower people in the aftermath of major natural disasters. Also, there have been many attempts to help marginalized people, such as the homeless, the poor or the handicapped, through art. These attempts help participants gain or regain social connectedness and communication skill in various ways. In Yogyakarta and Surakarta, starting around year 2002 or 2003, several teachers of art institutions, such as Indonesian Institute of Arts (ISI) Yogyakarta and ISI Surakarta, began to focus on art education for handicapped children. Through this, many handicapped children have gained self-confidence, their fear of social interactions having been lessened. Not only modern arts but local traditional arts have been often used for this purpose. I also saw some artistic communities 
playing important roles of empowering people in the aftermath of the earthquake at Yogyakarta in 2006 and Mount Merapi's eruption in 2006 and 2010. As the role of art in society has been changing, the role of art management has been changing.

\section{MATERIALS AND METHODS}

In this paper, I examine the activities by a community network named Tlatah Bocah (child friendly area), based at Mount Merapi, Magelang regency in the province of Central Java to discuss their methods of art management and the benefit of them to the communities involved to find out how the traditional art is used in the communities in modern context and see the possibility of traditional art to survive for the future. The method of this research is following. It was mainly done by participating and observing their activities and events and interviewing the people who were involved.

\section{DISCUSSION AND RESULTS}

Tlatah bocah

\section{General outline}

Tlatah bocah (child friendly area) is a community network which started in 2004 at the village communities on the slope of Mount Merapi, aiming to create a physical and psychological space for children by involving them in developing communities. It also aims to develop children's sensitivity toward social reality, environment, and human relations in daily life. Among the learning media are the traditional folk arts from their own villages which embrace the values of care for others and solidarity of the communities. Their slogan is "Bocah dudu dolanan, bocah kudu dolanan (A child is not a toy, a child needs to play)". In 2007, Tlatah bocah initiated a children's traditional art festival to campaign for children's rights. The theme was transforming value of the education through the cultural and artistic movements. Since then, this cultural festival has been done every year with themes related to children's issues.

The founder, Gunawan Julianto is originally from Muntilan, a sub-district located at the base of Mount Merapi. He is not an artist himself and is not very interested in art. His background is business management. He intended to have some positive activities for children at the villages in Mount Merapi which residents can actively participate in or even can lead themselves. The reason he chose to manage artistic activities were:

1. Many villages at Mount Merapi had their own, unique traditional folk performing arts even though many of the folk performing art groups were no longer active.

2. By using local art and art groups, residents could consider the activities by Tlatah bocah as their own issue and could help or even lead the events enthusiastically. It would lead to transmit their tradition from generation to generation.

3. There were very few children's folk performing arts groups.

\section{Activities by Tlatah bocah}

Children's traditional art festivals are the main activity of Tlatah bocah. In the festivals, mainly the children's folk performing art groups perform. Occasionally, some adult 
groups perform. It is expanding rapidly each year. Only six children's groups of folk performing art from one sub-district performed at the first Tlatah bocah art festival. These villages did not have fixed children's groups (They occasionally had some children's performances, but never had fixed group by children). However, they formed them in response to Gunawan's invitation to participate in the festival. After the second year, aside from the first year's groups, nearby village communities wanted to join and formed children's groups of their own.

The festivals actually became the phenomena and many communities started to participate in them. In addition, Gunawan himself frequently invites different villages to join the festivals and suggests that they form children's performing groups. The effort is rewarded and there are new children's groups participating in the festival every year. Incredibly, the groups which started for the first festival are still very active.

The network is constantly expending. Presently, the village communities in Mount Sumbing, Mount Merbabu and remote area of Mount Menoreh joined the network and many art communities from four regencies (Magelang, Boyolali, Salatiga and Kulon Progo) drive Tlatah Bocah.

The other activities by Tlatah bocah also have been expanding each year. I will introduce the activities in 2013 as an example.

"Tlatah bocah children's traditional art festival VII"

1. Merti Jiwo (June $22^{\text {nd }}-23^{\text {rd }}$ ) - held as the opening of the art festival series by Tlatah bocah this year. It was held as a ritual to purify oneself, explore the nature and understand the life.

2. Hajat Seni (July $6^{\text {th }}-7^{\text {th }}$ ) - The festival of folk performing arts held at Gumuk village on the slope of Mount Merapi to campaign children's right. Performers came from Mount Merapi, Mount Sumbing, Mount Menoreh, Jakarta, Surabaya, Grobogan, Salatiga, Surakarta, Temanggung, Kulonprogo and Yogyakarta.

3. Biasiswa Seni (August $16^{\text {th }}$ ) - held in Jakarta to share the activities of Biasiswa Seni (art scholarship) by Tlatah Bocah.

4. Laku Lampah (August $24^{\text {th }}-25^{\text {th }}$ ) - Another festival of folk performing arts held outside of Mount Merapi. This year, it was held at Sambak village on the slope of Mount Sumbing.

5. Larung Sukerta (September $7^{\text {th }}$ ) - held as the closing ceremony of the art festival at Telogolele village on the slope of Mout Merapi. This event consisted of the traditional ritual to remove negative elements of one's life and the exploration of self and nature from movements. Also, this event symbolized the flow of the traditional art from one generation to the next.

Gunawan Julianto, the founder of Tlatah bocah stated as given below about the festival: One of the aims to have the art festivals for children at Mount Merapi is to protect a sense of solidarity of people. In 2012, thirty communities (about 1500 people) were involved in the preparation of the festival for two months providing time, energy and materials. People in Mount Merapi has the way of thinking simply which prioritize 
solidarity, mutual aid (gotong royong), tolerating and respecting others (tepo seliro) whereby seen in the traditional management such as local ritualistic customs and arts of each village.

In addition, people also tolerate the existence of different religions and beliefs to live in harmony. It is a reflection of the State of Indonesia which consists of a variety of languages, traditions, ethnicity, etc. Nevertheless, in the past two decades, many unusual violent incidents occurred on behalf of the tribes, religions, races, and classes in some areas of Indonesia without complete solutions that could trigger national disintegration. Concerning issues which addressed above, Tlatah bocah art festivals, with campaigning mutual aid (gotong royong), raises cultural wealth of Merapi communites as well as communities in different area in order to establish unity, harmony and tolerance as the foundation of nation-building (From an interview with Gunawan Julianto on July 12, 2013).

This year, a total of 38 groups performed in the festival.

"Chicken scholarship (Beasiswa ayam)"

Tlatah bocah is giving out chicks to the children between 4th to 9th grades at Mount Merapi to support their education funds. A child can raise a chick and sell eggs or meat, or breed it to pay for his/ her school expenses. It is also aimed to teach children self-support. Eventually, the child has to pay it back to Tlatah bocah.

"Art scholarship (Beasiswa seni)"

The idea of the art scholarship is to support the art communities in the villages to stay active. Usually people who are active in art world of the villages spend most of their time for the arts in the communities. However, they usually do not gain any income from it. When outsiders support such art communities, they will surely feel happy, proud and become more active in artistic activities. The idea is anyone can give ' a little ' of his/her resources, for example one thousand rupiah, and it will be the driving force of those art communities. For example, such small scholarships can be used to fix costumes, have concerts, repair or build the places for art activities, buy needed musical instruments and so on.

"Srawung gunung (Mountain-style interaction)"

This is a program for exchange between villagers from Tlatah bocah community and the outsiders. The villagers have been hosting several groups or individuals from either inside or outside of Indonesia in their villages to create art pieces together, give workshops and so on.

\section{About the sources of funds}

Tlatah bocah is mainly getting funds from the contributions/supporters from the cities such as Jakarta and Yogyakarta. The unique thing is for the festival, they get funds from collecting the contributions of used clothing from people in Jakarta and Yogyakarta. Then, the villagers sell them at their villages. The money from it becomes 
the funds to run the festival each year. I believe that it helps to raise a sense of independency among villagers, therefore, they can feel it is really their own festival.

Influences of Tlatah bocah in the communities of mountain villages

First of all, I briefly examine the influences of the activities by Tlatah bocah in the village communities.

1. There are surely more art activities in these villages which participated in the Tlatah bocah's activities. In many villages, they already had adult folk performing arts groups, but most of them were not very active before the art festival by Tlatah bocah, children's groups, even less so.

2. More communications between adults and children through art activities. (One generation to the next. Vertical relation).

3. The unity of the community was strengthened because the members of village community help each other to have their children perform and to put on the festival successfully. Some people actually return to their home villages from their current residences in order to help put on the festival. Hosting the festival is an especial honor for the host village.

4. More connection between village communities nearby. (Horizontal relation).

5. More exchange with the communities outside of their own areas. The groups from outside of Mount Merapi started to join the festivals since 2009.

6. More outsiders are coming to the villages. It can lead to vitalize the village communities

Deserving special mention is one village called Sumber in Mount Merapi that created a community space supported by Tlatah bocah. The land was donated by the leader of the performing art group of the village. Tlatah bocah helped a part of the cost to build the space and buy gamelan instruments through their art scholarship program. It became a sanggar (art studio or small private art school) called Bangun Budaya (cultural awakening) and became the community space for the villagers at the same time. This space has been used very actively both as the place for art activities and the place which villagers mingle. Before they had this space, it was difficult for them to gather because they did not have any space for it. Now, various people frequent the space and it has become a communication and planning center for the village. It became a very important space for the member of the community. Also, outsiders are allowed to rent the space for artistic activities.

Another important point to be mention is that Tlatah bocah is the periodic organization of art festivals. By having periodic events, rather than single events, community can be vitalized more. At the same time, there will be more possibility to vitalize their unique folk art and continue to the next generations.

At the same time, Tlatah bocah made some village communities very open to outsiders as can be seen in one of their programs Srawung gunung. For example, a group of Australians came and studied local performing arts, and a French woman stayed for two months to create a theater piece with local children. Community members have been also hosting visitors from other parts of Indonesia, giving art workshops and introducing them to village life. They also can be stimulated and get new inspiration 
from outsiders that can lead to the creation of new arts and to develop a more open and flexible community.

Challenges facing Tlatah bocah's activities

Even though Tlatah bocah offers many positive activities which are well accepted by some village communities in Mount Merapi, there are some less positive results as well. First of all, this organization formed around the charismatic character of the founder. He has many cooperators, however, it is undeniable that cooperators get together because of his character and villagers agree to cooperate with Tlatah bocah because he is the leader. He is the only driver of this organization so far. The other problem is that most village communities which he approached are still really depending on him to initiate activities even though they work to manage the activities once initiated. This is the weak point of this organization. Without him, there is a distinct possibility that all the unique activities will not continue and it will become just another "event". Here I see the limit of art and community management such as this kind. In addition, because village communities are depending on him to initiate activities, there is jealousy between communities which are chosen to have activities and which are not chosen to have it by him.

The biggest concern I see is that, by putting local traditional performing arts onto the stage (even through it is a simple stage in a village), the art itself can be changed. It can be more focused as an art 'to be watched and enjoyed by the audience' rather than ritualistic character which many traditional performing arts from this area have. I cannot say it is simply an undesirable change because the art, even the traditional art, have to be changed in accordance with the change of time to survive. However, it should be done carefully and not only curry favor with the public now. Rapid change might destroy the meaning and identity of the traditional arts of this area. It might also be a cause for some villagers to be discriminated from the arts because they cannot perform well. Besides, every year, the performers for the festival of Tlatah bocah are getting younger and younger. It can be good but I am not sure how it effects to the art itself and community because some of the art forms are traditionally not really for young children. To answer those unclear points above, I need longer time to research. This will be one of my subjects of researches in the near future.

\section{CONCLUSION}

The role of Tlatah bocah in the communities of mountain villages: from the art management perspective

I demonstrate the most important aspect of Tlatah bocah's art management style is mediation. They are connecting communities, contributors and recipients, adults and children, and outsider and insiders. They mediate effectively because they are outsiders themselves and they respect the autonomy of the communities they work with. Not only do they respect it, but also they skilfully lead the communities not to be very dependent on them and make the community members feel the festivals are actually their own events. The way they raise funds for demonstrates this fact. 
While they could give some money to execute the festivals from donors directly to the villagers, they instead encourage the villagers to make efforts to raise funds by selling donated and used clothing on their own. It really involved them more deeply in the festivals.

Tlatah bocah is actually hoping that more independent, periodic events which are totally organized by the village communities are going to emerge, learning from the festivals by Tlatah bocah. In fact, the first Tlatah bocah festival was done at Gowok Pos village in relation to their annual event call rejeban in the month of Rejeb (A month in Javanese lunar calendar which is adapted from the use of months in the Islamic calendar. It is 2 months before Ramadan month). Tlatah bocah chose to have their festival at that time because before and at the time of event, the villagers got together and worked together. Therefore, it was easier to get help, such as setting up performing stage for the festival, from the villagers. In addition, at the time of the event, it was the tradition of the village that every house has open house to treat any visitors food. Usually they cook more food than they need, so there is always extra food for visitors.

Consequently, it was a perfect timing for Tlatah bocah to start the festival because all the participants in the festival are not paid and the only thing they need is to be fed and to have accommodations for a small number of people who are visiting from far away. Furthermore, the villagers were all very happy to have the Tlatah bocah event because it was adding new value to the village's important event. Tlatah bocah held three consecutive festivals there. From the fourth one, the festival started to be held in the different village each time, however, the villagers in Gowok Pos eager to have the festival at their village again. Tlatah bocah is suggesting them to organize it themselves because it is in fact not very hard to do it if it is done at the time of rejeban. Tlatah bocah is ready to help if the people in Gowok pos are really up to do it. The importance is the villager's autonomy to really promote good, continuing change in the village community. Gunawan, the founder of Tlatah bocah, is hoping that all the villages where Tlatah bocah ever had the festivals will continue the festival themselves and make it to their own periodical event in the community. It has not happened yet, however, many villages in the area already have annual community events such as rejeban at Gowok Pos, hence, there are some hopes.

Besides, the children can learn the spirit which is included in the traditional folk art such as mutual aid, tolerance and respect to the others, by learning the traditional folk art for performing in the festivals. Those spirits are nothing more than very important qualities to create good village communities. Local arts often embrace the qualities which are most needed in those communities. Therefore, it is very useful for children to learn local arts. Tlatah bocah widen the chances for children to learn those values. Also, it is improving the positions of the children in the communities. Another remarkable point is their openness to outsiders. By accepting and inviting many outsiders to join the activities, Tlatah bocah successfully widen the range of activities and bring in more supporters. In fact, many outsiders are helping the activities by donating resources, not only money but the manpower and the creative ideas also. 
The village communities also get many benefits from it such as vitalizing the villages, learning from the outsiders and even getting some financial incomes. However, it is like a double-edged sword. It also includes the danger of the arts to curry favor with the outsiders and popularity.We can also the role of Tlatah bocah as a mediator or a catalyst from the all incidents mentioned above.

After joining, observing and researching some activities by Tlatah bocah, what I keenly felt was the importance of having good art manager to successfully execute the program like this. Presently, it is still left to the talents of individuals, however, raising good art managers will be the next important task. A good art manager is not egoistic and can accomplish the important role in developing a community as a mediator. In other words, this is actually a community management using art as a catalyst rather than an art management. The boundary between the art management and the community management is unclear and it may be hard to be separated off from each other nowadays. The important point is that the activities of Tlatah bocah put a process in motion to vitalize the village communities, to continue the local folk arts and to improve the children's positions in the communities. At the same time, they are taking parts in adding new value to local traditional arts because their activities were mainly done with local traditional arts which tend to be slighted up in the present society. I demonstrate this new kind of art management can add new role and new value to traditional performing arts and empowering local communities. It is possible that this will lead traditional performing arts to be necessary in modern society and continued to the next era.

\section{REFERENCES}

Budi Raharja, Andono Puji Astuti, \& Tri Manto. (2002), Perancangan Gamelan Anakanak: Sebuah Strategi Pengenalan Gamelan Pada anak Usia Prasekolah, Laporan Hasil Penelitian, ISI Yogyakarta.

Budi Raharja, Nelia Ramdhani \& H. Abdhul Gofir. (2009), Terapi Autis Melalui Permaina Musik, Laporan Penelitian, ISI Yogyakarta.

Caballero, Rodrigo. (2010), Applied Gamelan: Approaching health-engaged research in ethnomusicology, University of British Columbia, Vancouver.

Caulfield, Laura, David Wilson, \& Dean Wilkinson. (2010), Continuing Positive change in Prison and the Community: An Analysis of the long-term and wider impact of the Good Vibrations Project, Center for Applied Criminology, Birmingham City University.

Desy Dwi Pamuri. (2004/2005), Tari Sebagai Media Pembelajaran DI Yayasan Anak Wayang Indonesia Yogyakarta,, Skripsi S-1, ISI Yogyakarta.

Haraguchi, Tsuyoshi et al. ed. (2011), Kamagasaki no Susume (Exhortation of Kamagasaki), Rakuhoku-Shuppan, Kyoto.

Harima, Yasuo (The chief director of Tanpopo-no-ye foundation). (2006), Social Inclusion - Support each other and join the differences (Social Inclusion - Sasaeatte chigai wo tunagu), Bukkyo University.

Harima, Yasuo (The chief director of Tanpopo-no-ye foundation). (2010), Able Art: Proposing new value (Able Art: Atarashii kachi wo teiansuru), Tanpopo-no-ye foundation, Nara.

ISI Surakarta. (2007), LAPORAN KEGIATAN PPM (Pelatihan Karawitan) terhadap anak-anak SLB A SURAKARTA.

ISI Surakarta. (2009),Laporan PPM (Pelatihan Karawitan) terhadap anak-anak LAPAS Kuthoarjo. 
Kawasaki, Kenichi et al. (2002), Art Management, Hoso Daigaku Kyoiku Shinkokai, Tokyo.

Kotane Seisaku Iinkai. (2009), Kokoro no Tane to shite (As a seed of heart), Kokoroom Bunko, Osaka.

Nakagawa, Shin et al. ed. (2011), Korekara no Art Management: Social Share heno Michi (Art Manegement from now on: the Way to Social Share), filmart-sha, Tokyo.

Nakagawa, Shin. (2013), Art no chikara (The Power of Art), Izumi Shoin, Osaka.

Nishimura, Yumi. (2007), Kouryu suru Karada: Care wo Toraenaosu (Interchanging body: re-understanding care), NHK Books, Tokyo.

Okado, Kaori.(2012), The New Role of Javanese Traditional Performing Arts: A Case Study of Educational and Socially Transformative Gamelan Music Programs in Prisons, Journal of Urban Culture Research, Vol. 5, pp. 70-85, Chulalongkorn University, Bangkok/ Osaka City University, Osaka.

Okado, Kaori. (2011), When Women are Kings: Cross-Gendered Expression in an All-Female Central Javanese Court Dance-Drama and Its Public Reception, Urban Scope (internet journal), Vol. 2, Osaka City University, Osaka.

Ryo, Michiko ed. (2010), The Poetic Works of Prisoners in Nara Juvenile Prison (Nara shounen keimusho shishu), Nagasaki-shuppan., Tokyo.

Sasaki, Masayuki and Mizutani, Toshio ed. (2009), Souzou Toshi to Shakai Housetsu (Creative City and Social Inclusion), Suiyou-sha, Tokyo.

Sri Ardiati. (2006/2007), Upaya Penemuan Teknik Penyampaian Tari Bagi Penyandang Tuna Wicara di Panti Tuna Netra dan Tuna Rungu Wicara Dharma Putra Purworejo, Skripsi S-1, ISI Yogyakarta.

Sumandiyo Hadi, Prof. Dr. Y. et el. (2002), Studi Eksperimen Model Pembelajaran Gerak Olah Tubuh (Tari) Sebagai Terapi Bagi Anak-Anak Tunagrahita, sebuah penelitian kelompok, ISI Yogyakarta.

Sumandiyo Hadi, Prof. Dr. Y. et el. (2003), Uji Coba/Sosialisasi Pengembangan Model Pembelajaran Gerak Olah Tubuh (Tari) Sebagai Terapi Bagi Anak-Anak Tunagrahita, sebuah penelitian kelompok, ISI Yogyakarta.

Tanpopo-no-ye foundation ed. (2008), Accept the difference and think about the differenceChildren with developmental disability and art activities (Chigai wo mitome, chigai wo kanngaeru - hattatsu shougai no aru kodomo to a-to katudou), Nara.

Toetiek Septriasih.(2009), Bermain Gamelan Untuk Meningkatkan Perilaku Prososial Pada remaja Bermasalah, Naskah Publikasi Tesis S-2, Pascasarjana S-2 Psikologi UGM. 